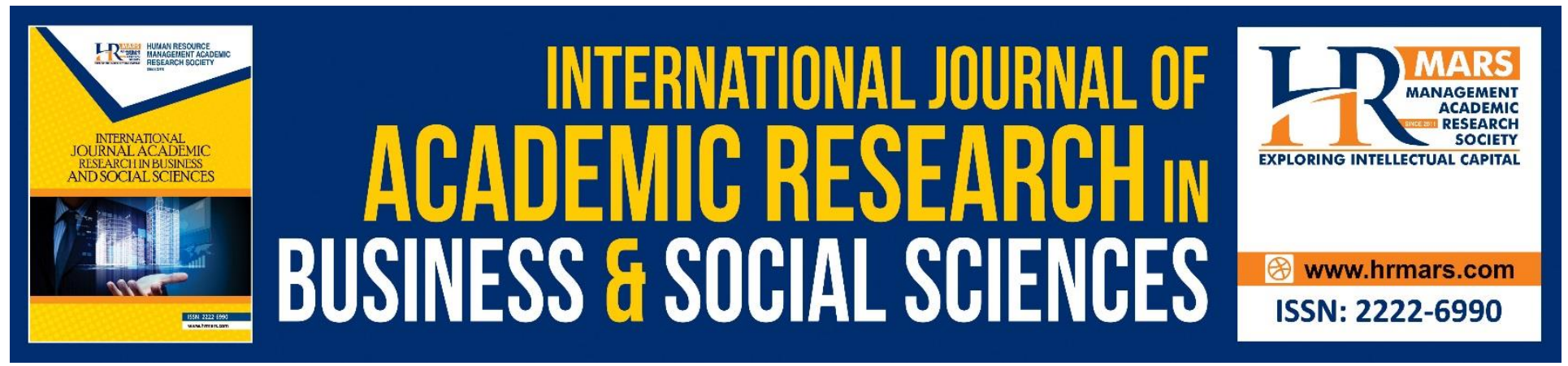

\title{
The Comparison of Depression, Anxiety, Stress, and Coping Strategies among Malaysian Male and Female During COVID- 19 Movement Control Period
}

Asma Perveen, Saeid Motevalli, Hazalizah Hamzah, Fatanah Ramlee, Salami Mutiu Olagoke, Azizah Othman

To Link this Article: http://dx.doi.org/10.6007/IJARBSS/v10-i7/7451

DOI:10.6007/IJARBSS/v10-i7/7451

Received: 08 April 2020, Revised: 16 May 2020, Accepted: 23 June 2020

Published Online: 21 July 2020

In-Text Citation: (Perveen et al., 2020)

To Cite this Article: Perveen, A., Motevalli, S., Hamzah, H., Ramlee, F., Olagoke, S. M., \& Othman, A. (2020). The Comparison of Depression, Anxiety, Stress, and Coping Strategies among Malaysian Male and Female During COVID-19 Movement Control Period. International Journal of Academic Research in Business and Social Sciences, 10(7), 487-496.

Copyright: (C) 2020 The Author(s)

Published by Human Resource Management Academic Research Society (www.hrmars.com)

This article is published under the Creative Commons Attribution (CC BY 4.0) license. Anyone may reproduce, distribute, translate and create derivative works of this article (for both commercial and non-commercial purposes), subject to full attribution to the original publication and authors. The full terms of this license may be seen

at: http://creativecommons.org/licences/by/4.0/legalcode

\section{Vol. 10, No. 7, 2020, Pg. 487 - 496}

Full Terms \& Conditions of access and use can be found at http://hrmars.com/index.php/pages/detail/publication-ethics 


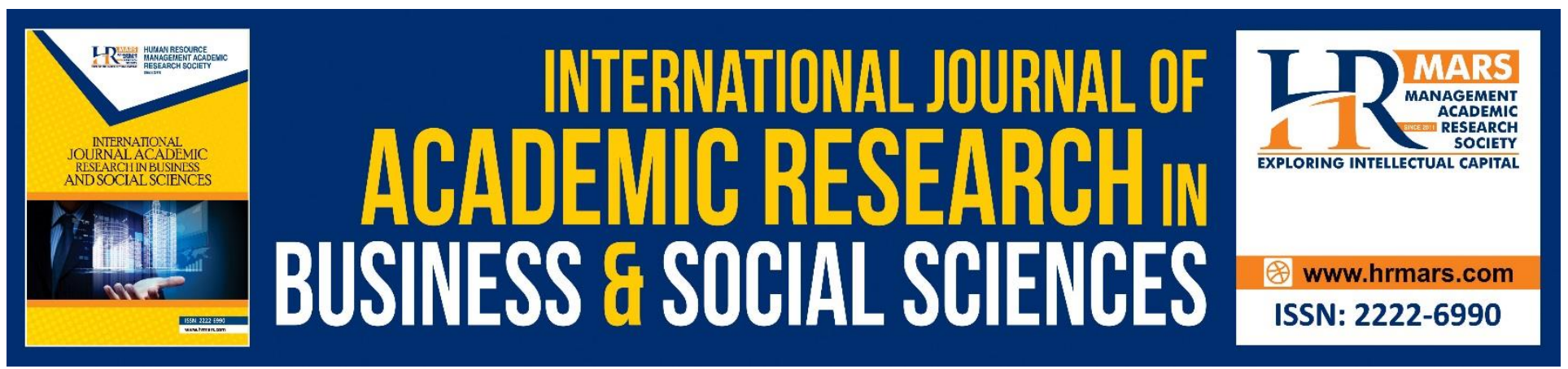

\title{
The Comparison of Depression, Anxiety, Stress, and Coping Strategies among Malaysian Male and Female During COVID-19 Movement Control Period
}

\author{
Asma Perveen, Saeid Motevalli, Hazalizah Hamzah, Fatanah \\ Ramlee, Salami Mutiu Olagoke Azizah Othman \\ University Pendidikan Sultan Idris, Malaysia, ${ }^{6}$ University Sains Malaysia
}

\begin{abstract}
Covid-19, pandemic effected the global health, physically, socially and mentally. Currently the pandemic in Malaysia observed to be in control with movement strict precaution and preventions. This study is cross-sectional survey study to evaluate the responses of Malaysian Adults during the COVID-19 pandemic in Malaysia. To evaluate the Malaysian responses and effects on their psychological health and coping response, a cross sectional online survey was conduct on $(\mathrm{N}=716)$ adult participants age range 20 to 75 years (Mean 33.34), male (193) female (523) from various background and all district of Malaysia. Questionnaire Depression, Anxiety, and Stress Scale (DASS), and Brief Coping Response Inventory (BCRI) was administer to evaluate the response through online Google form. Results revealed that there is significant gender differences in the score of psychological health related to, depression, anxiety and stress with coping response. Results, A Mann-Whitney $U$ analysis indicated that there was a difference $(Z=-2.013, p<.05)$ indicated that male stress score higher than female during the COVID-19 movement control period. Coping response showed higher significance with male as compared to females. Our findings revealed high levels of depression, anxiety, and stress symptoms among both gender, with the differences in coping response towards the pandemic phase of COVID-19, during movement control period. As Mental health practitioner, there is great needs to address the mental health status and coping responses, for the wellbeing of adults during the unprecedented phase of COVID-19 pandemic.
\end{abstract}

Keywords: Depression, Gender, COVID-19, Pandemic, Coping.

\section{Introduction}

COVID-19 has become the biggest ever challenge around the globe and caused a lot of physical restriction, social barrier and financial strain among community. Movement control order was strictly followed by the people in Malaysia from $18^{\text {th }}$ March to onward, still there is movement control order until $30^{\text {th }}$ May2020. The restrictions imposed have enabled in flattening the infections curve in the country, according to health officials. The Malaysian Institute of Economic Research (MIER) estimated the cases to increase at a rate of $12.5 \%$ per day but the actual increase is $7.5 \%$ per day (Government 
INTERNATIONAL JOURNAL OF ACADEMIC RESEARCH IN BUSINESS AND SOCIAL SCIENCES Vol. 10, No. 7, July, 2020, E-ISSN: 2222-6990 @ 2020 HRMARS

of Malaysia officials, 2020). Efforts to prevent the virus spreading include travel restrictions, quarantines, movement control order, event postponements and cancellations, and facility closures (Gao et al. 2020). Schools and universities have closed either on a nationwide or local basis in more than 210 countries, affecting more than 3.1 billion population directly and indirectly (The Straits Times, 2020). The transmission routes of infectious diseases are and thereby accordingly take self-protective measures against pandemic diseases related to washing hands, using mask, using sanitizer, maintain social distance, measures such as contact, droplet, and air route isolation methods (or a combination of the three) are used to prevent disease transmission to other patients, visitors, or health professionals (Evirgen et al. 2014).

Staying indoor during a lockdown like in the current covid-19 pandemic was one of the finest mean of minimising the spread of virus-related diseases and for controlling and quelling the spread of viruses and contamination agents (WHO, 2020). At the same time it has massive impact on psychological health, it has caused significant fear and stress to male and female (Kuschner, 2017). Quarantine differs from isolation, which is the separation of people who have been diagnosed with a contagious disease from people who are not sick; however, the two terms are often used interchangeably, especially in communication with the public. (Baden and Rubin, 2020). In Malaysia the population response toward quarantine was understanding. Mostly people followed the movement rules and announcement towards the precaution, like restriction for unnecessary movement and penalty for moving with rationale reasons. People were allowed to do grocery once a week, travel with unavoidable reasons, one person on vehicle was allowed to move within the city and town boundaries (Crisis Preparedness and Response Centre, 2020). People were instructed to follow the guideline and procedures issued by Ministry of Health Malaysia accordingly (Health Ministry of Malaysia, 2020). Hence, when people are exposed to accurate and accessible information from health authorities. During the initial evaluation, moderate-to-severe stress, anxiety and depression were noted in $8.1 \%, 28.8 \%$ and $16.5 \%$, respectively and there were no significant longitudinal changes in stress, anxiety and depression levels ( $p>0.05)$. Protective (Wang et al. 2020). The movement control order is a hard and emotionally painful experience, separation from loved ones, the loss of freedom, uncertainty over disease status and feelings of boredom and frustration can create dramatic effects on mental health among female and male. The potential benefits of required movement control order, need to be weighed carefully against the possible psychological costs (Brooks et al. 2020). Loss of usual routine, and reduced social and physical contact with others, shown to cause boredom, frustration, and a sense of isolation from the rest of the world, which was distressing to the people (Anon, 2020) in reference to different gender role. Coronavirus anxiety was found to significantly influence social attitudes and the frustration intensified by not being able to do daily living activities such as going outside doing necessities things and taking part in social activities (Lee and Lee, 2020). The movement control orders, and coronavirus anxiety leaded to unavoidable psychological consequences(Huang and Zhao, 2020), people are using different strategies to deal and overcome their fear, anxiety and feeling of sadness during the phase of COVID-19 movement control order in Malaysia. The current research aimed to find out the differences of mental health status and coping response among male and female Malaysian adults during the pandemic COVID-19 movement control period. 
INTERNATIONAL JOURNAL OF ACADEMIC RESEARCH IN BUSINESS AND SOCIAL SCIENCES

Vol. 10, No. 7, July, 2020, E-ISSN: 2222-6990 @ 2020 HRMARS

\section{Hypothesis}

$\mathrm{H}_{\text {null1 }}$ : There is no difference in the stress, anxiety and depression rank of Malaysian male and female during the pandemic of COVID-19.

$\mathrm{H}_{\text {null2: }}$ : There is no difference in the Coping response among Malaysian male and female during the pandemic of COVID-19

\section{Method}

The cross-section survey design through online Google form was conduct on $(n=716)$ adult's participants with convenient sampling. The online survey design was chosen based on the COVID-19 movement control order situation. As survey design is commonly used to collect data from wide range of participants. The participants were from the $(n=15)$ states of Malaysia. The target population as the chosen sample to be participants with an above 18 years old from all states of Malaysia. Online sample size calculator in context to population estimation, with a margin of error of $5 \%$ and sample population of $21,238,874$, with the Confidence Level $95 \%$, the estimated 700 participants. The sample of study was 716 participants. The online links to the Google Form which contains the questionnaires was distributed through social media, whatsapp and emails during the $1^{\text {st }}$ and $2^{\text {nd }}$ phase of COVID-19 pandemic movement control order. Once the link was opened, the consent form included the objective, significance, the importance of confidentiality of each participants was provided. Participants were required to answer three sections demographic, Depression, anxiety and stress scale DASS-21 (Coker, Coker, and Sanni 2018) and Brief Coping Response inventory (Yusoff, Low, and Yip 2010). Upon completion, participants submitted the answers which were anonymous and kept confidential except the researchers. Ethical approval of the human survey online research was obtained from Research Management and Innovation Center of Sultan Idris Education University. Data was analyzed to study variables descriptive analysis and differences in the variable score among male and female Mann Whitney test.

\section{Results}

Results of study indicated that there was significant difference in the score of male and female related to the rank of stress, anxiety and depression, and coping response. The descriptive statistic showed that the age range of $(n=716)$ 18-69 years (Mean=33.07) and Male 193, female 523 participated in the study. The most participants were, from Selangor state of Malaysia, which was declared red zone during the Movement control period of COVID-19 pandemic movement control phase.

\section{Descriptive Statistics for DASS and Gender}

Table 1: Descriptive statistics of stress, anxiety, and depression among male and female

\begin{tabular}{llllllll}
\hline Variable & Gender & $\mathrm{N}$ & $\begin{array}{l}\text { Mean } \\
\text { Rank }\end{array}$ & $\begin{array}{l}\text { Sum of } \\
\text { Ranks }\end{array}$ & 25 & 50 & 75 \\
\hline Stress & Male & 193 & 333.27 & 64321.5 & 7 & 9 & 12.5 \\
& Female & 523 & 367.81 & 192364.5 & 7 & 9 & 13 \\
Anxiety & Male & 193 & 336.19 & 64884.5 & 7 & 8 & 11.5 \\
& Female & 523 & 366.73 & 191801.5 & 7 & 9 & 12 \\
Depression & Male & 193 & 333.58 & 64380.5 & 7 & 8 & 11 \\
& Female & 523 & 367.70 & 192305.5 & 7 & 9 & 12 \\
\hline
\end{tabular}


INTERNATIONAL JOURNAL OF ACADEMIC RESEARCH IN BUSINESS AND SOCIAL SCIENCES Vol. 10, No. 7, July, 2020, E-ISSN: 2222-6990 @ 2020 HRMARS

As table 4.1 indicates that male received significantly smaller mean rank of stress (333.27) compared to the female (367.81). Male also received significantly smaller mean rank of depression (333.58) compared to the female (367.70). On the other hand, Male received smaller mean rank of anxiety (336.19) compared to the female (366.73).

Table 4.2: Mann Whitney U test for Stress, Anxiety, and Depression

\begin{tabular}{llll}
\hline & Stress & Anxiety & Depression \\
\hline Mann-Whitney U & 45600.500 & 46163.500 & 45659.500 \\
Wilcoxon W & 64321.500 & 64884.500 & 64380.500 \\
Z & -2.013 & -1.791 & -1.998 \\
Asymp. Sig. (2-tailed) & .044 & .073 & .046 \\
\hline
\end{tabular}

a. Grouping Variable: Gender

A Mann-Whitney $U$ test was conducted table 4.2 to determine whether there was a difference in the level of stress, anxiety and depression among of Malaysian male and female during COVID-19. Results of that analysis indicated that there was a difference, $Z=-2.013, \mathrm{p}<.05$ or $(U=45600.5, p=.044, r=$ -.075) with male stress higher than female during the COVID-19. There was no difference, $Z=-1.791$, $p>.05$ or $(U=46163.5, p=.073, r=-.067)$ with male anxiety score as compare to female during the COVID-19. There was difference in the level of depression of male $Z=-1.998, p<.05$ or $(U=45659.5$, $p=.046, r=-.075$ ) as compared to female Malaysian during COVID-19.

\section{Coping and Gender}

Table 4.3. Differences of coping strategies among male and female

\begin{tabular}{lllll}
\hline Variable & Gender & N & & \\
& & & Mean Rank & Sum of Ranks \\
\hline Self-distraction & Male & 193 & 330.24 & 63735.50 \\
& Female & 523 & 368.93 & 192950.50 \\
Active coping & Male & 193 & 337.65 & 65166.00 \\
& Female & 523 & 366.20 & 191520.00 \\
Denial & Male & 193 & 386.01 & 74499.50 \\
Substance abuse & Female & 523 & 348.35 & 182186.50 \\
& Male & 193 & 335.58 & 64766.00 \\
Emotional support & Female & 523 & 366.96 & 191920.00 \\
& Male & 193 & 344.54 & 66495.50 \\
Instrumental support & Memale & 523 & 363.65 & 190190.50 \\
& Male & 193 & 350.24 & 67596.00 \\
& & & & 189090.00
\end{tabular}


INTERNATIONAL JOURNAL OF ACADEMIC RESEARCH IN BUSINESS AND SOCIAL SCIENCES Vol. 10, No. 7, July, 2020, E-ISSN: 2222-6990 @ 2020 HRMARS

$\begin{array}{lllll}\text { Behavioural engagement } & \text { Male } & 193 & 357.55 & 69008.00 \\ & & & & \\ \text { venting } & \text { Male } & 523 & 358.85 & 187678.00 \\ & \text { Female } & 523 & 373.48 & 195332.00 \\ \text { Positive reframing } & \text { Male } & 193 & 388.02 & 74888.50 \\ & \text { Female } & 523 & 347.61 & 181797.50 \\ \text { Planning } & \text { Male } & 193 & 353.04 & 68136.00 \\ & \text { Female } & 523 & 360.52 & 188550.00 \\ \text { Humor } & \text { Male } & 193 & 318.36 & 61443.00 \\ \text { Acceptance } & \text { Female } & 523 & 373.31 & 195243.00 \\ & \text { Male } & 193 & 358.30 & 69152.00 \\ \text { Religion } & \text { Female } & 523 & 358.57 & 187534.00 \\ & \text { Male } & 193 & 347.26 & 67020.50 \\ \text { Self-blame } & \text { Female } & 523 & 362.65 & 189665.50 \\ & \text { Male } & 193 & 331.70 & 64017.50 \\ & \text { Female } & 523 & 368.39 & 192668.50\end{array}$

Table 4.3. Indicates that the mean rank of coping strategies for Malaysian male and female during the COVID-19.

Table 4.4: Mann Whitney U test for Copying Strategies

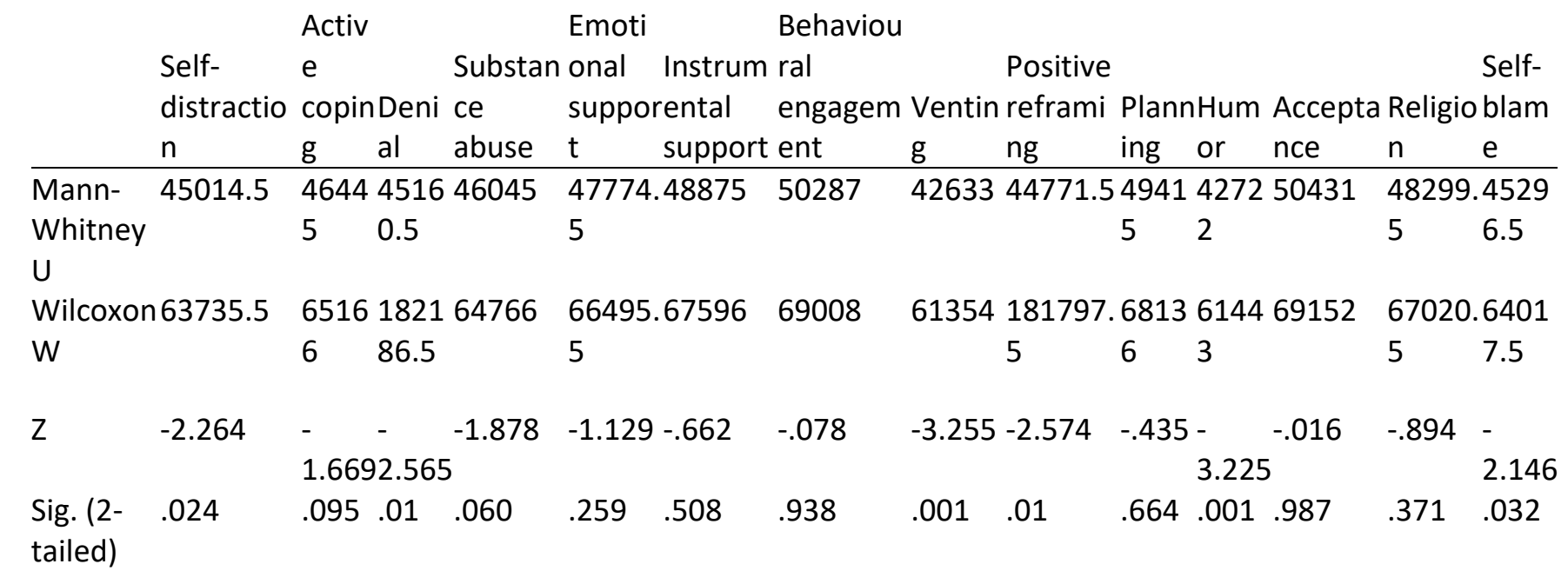

a. Grouping Variable: Gender 
INTERNATIONAL JOURNAL OF ACADEMIC RESEARCH IN BUSINESS AND SOCIAL SCIENCES

Vol. 10, No. 7, July, 2020, E-ISSN: 2222-6990 @ 2020 HRMARS

A Mann-Whitney $U$ test was conducted to determine whether there was a difference in the level of coping components of Malaysian male and female during COVID-19. Results of that analysis indicated that there was a significant difference, $Z=-2.264, p<.05$ or $(U=45014.5, p=.024, r=-.08)$ with male self-distraction higher than female, $Z=-2.565, p<.01$ or $(U=45160.5, p=.01, r=-.09)$ with male denial higher than female, $Z=-3.255, p<.01$ or $(U=42633, p=.001, r=-.12)$ with male venting higher than female, $Z=-2.574, p<.01$ or $(U=44771.5, p=.01, r=-.09)$ with male positive reframing higher than female, $Z=-3.225, p<.01$ or $(U=42722, p=.001, r=-.12)$ with male humor higher than female, $Z=-2.146, p<.05$ or $(U=45296.5, p=.032, r=-.08)$ with male self-blame higher than female during the COVID-19. Besides, the result of Mann-Whitney $U$ test did not show any significant difference in the level of Active coping, Substance abuse, Emotional support, Instrumental support, Behavioural engagement, Planning, Acceptance, and Religion of Malaysian male and female during COVID-19.

\section{Discussion}

Results indicated that the male and female were having significant rank of difference in score of depression, anxiety and stress. Coping response showed that there was significant difference on selfdistraction, denial, venting, positive reframing, and humor among male in comparison of female participants. Movement control period effected on many aspects of daily life functioning, these aspects, associated with a lack of quality of life, can lead to stress levels that negatively impact the physical, mental, and emotional health with both gender (Moutinho et al. 2017), with compromising daily routine functioning. Psychological impacts can be serious such as anxiety, insomnia, panic behaviour, fear, and hopelessness. In some cases viral outbreaks infect thousands of people, cause hundreds to thousands of fatalities and spread around the globe, thereby affecting millions of people to induce anxiety, panic behaviour, and other related psychiatric disorders (Khan, Siddique, and Shereen, 2020). The movement control order is effective strategy for people to prevent themselves from the COVID-19 pandemic, Mostly Malaysian are responding actively by managing social distance, wearing masks and washing and sanitizing their hands frequently. But at the same time the limited life activities and restricted movement is causing emotional frustration which was reported significant mong male as compared to female, the stress, anxiety and depression. The most common impacts of such an outbreak or pandemic could be anxiety, panic behaviour, sleep disturbances, disrupted daily biological rhythms, anger, and disappointment (Cao et al. 2020). The fear being infected is ultimately causing anxiety and stress higher among males as compared to females. Studies reported on general psychological symptoms, emotional disturbance, depression, stress, low mood, irritability, insomnia, post-traumatic stress symptoms (Brooks et al. 2020) were reported significantly higher during the movement control periods. Due to the sudden and highly infectious outbreak of COVID-19, it is causing inevitably anxiety, depression and other stress reactions amongst the population. With the new limitations on daily life and social activities for an unknown period of time, the population are predictably suffer from stress and anxiety and eventually may lose confidence in life, ultimately taking a toll on the mental health of society (Y. Wang et al. 2020). It is well-known that females are more likely to be depressed than males, both in terms of anxiety, stress and depressive symptoms (Gallo et al. 2018) However, in the current study the results showed that the male reported higher score as compared to female, related to stress and anxiety, there are possible explanation, as male have more chances to stay out home activities even during the movement control period and the international statistics (Biswas et al. 2020; Darwish, Ahmed, \& Pahi, 2020) also revealed that there 
are more higher percentage of male positive cases as compared to females. Psychosocial factors are vital in the aetiology of work stress and social and workplace stressors are likely to be different for men and women (Mark and Smith, 2018) during the phase of any crisis.

The current pandemic situation is stressful event for most of the world community in the current phase related to movement control orders situation. Malaysian adults are using different coping response to deal with this unpleasant pandemic experience. The results showed that the higher reported coping response were Self-distraction, Active coping, Substance abuse, Emotional support, Instrumental support, Behavioural engagement, Planning, Acceptance, and Religion among Malaysian male and female during COVID-19. Men may employ distracting forms to divert attention from their stress, anxiety and depressed mood, for example by working on different hobbies and playing games. In contrast, women were observed to have a ruminative style, that involves brooding and worrying, which serves to prolong and intensify the feelings of depression (Singh, 2020) men score higher on escape/avoidance and wishful thinking as compare to female(Mark and Smith, 2018). The study results revealed that there was higher score on coping response among male related to self-distraction, denial and venting. Experience stressful life event can lead towards the strategies of self-distraction, taking part in other activities, watching movies, playing games were found more frequent among male as compare to female(Green and Diaz, 2008). Gender difference was also noted in use of different coping strategies by the earthquake affected individuals. Female adult survivors were more devoted towards religious coping and passive coping whereas male survivors more frequently used active coping, social coping and self-distraction coping strategies (Sweileh, 2017). Male responded with adverse life events, using more frequently denial , self-distraction and venting, which is contradictory with previous studies finding, which indicate that women using more emotional coping strategies as compared to man (Tamres, Janicki, and Helgeson, 2002). In reference to gender difference, male use more problem solving strategies (Piko, 2001) as reframing positively the stressful events. During the COVID-19, the situation was uncontrollable for many dynamics, and its change the living styles to cope up with demands of newly developed role and responsibilities of social distance and personal hygiene. Adults reported using humor and religious activities (Wildman et al. 2020) to cope up with the social isolation and distance. To avoid the stress and anxiety of the situation the most adults reflected their belief toward religious (Dulmus and Hilarski, 2003), and creating their own self safety in their religious practices. The study contradicts in aspects of stress, anxiety, and depression prevalence among male is higher as compared to female, during COVID-19 movement control period. Study highlighted the difference of gender in relation to coping response toward the stressful situation, as male were using more emotional focused strategies as compare to female. To cope with such outbreaks and epidemics, the health care authorities should have affective plans, which must consider psychological health of both male and female.

\section{Conclusion}

Study concluded that COVID-19 is a tough period for nation to go through with this physical, and psychological impact, and it is frightening to be in midst of a worldwide pandemic. Malaysian population is responding actively despite of having uncertain and psychological impact. They are using different coping strategies to cope up with the current pandemic issues. To help community we need is to focus our attention to reassurance that we can deal and handle the transactions effectively. The current study has implication further to explore the dynamic of psychological impact 
INTERNATIONAL JOURNAL OF ACADEMIC RESEARCH IN BUSINESS AND SOCIAL SCIENCES

Vol. 10, No. 7, July, 2020, E-ISSN: 2222-6990 @ 2020 HRMARS

and coping strategies, which can help mental health practitioners to focus and address the issues appropriately and effectively.

\section{References}

Anon. (2020). World Social Report, 2020.

Baden, L. R., Eric, J. R. (2020). “Covid-19 - The Search for Effective Therapy." New England Journal of Medicine, 1-2.

Biswas, A., Uttaran, B., Alok, K. C., Devendra, N. T., Hasina, B., Shanta, D. (2020). "Emergence of Novel Coronavirus and COVID-19: Whether to Stay or Die Out?" Critical Reviews in Microbiology, 0(0), 1-12.

Brooks, S. K., Rebecca, K. W., Louise, E. S., Lisa, W, Simon, W., Neil, G., Gideon, J. R. (2020). "The Psychological Impact of Quarantine and How to Reduce It: Rapid Review of the Evidence." The Lancet, 395(10227), 912-20.

Cao, W., Ziwei, F., Guoqiang, H., Mei, H., Xinrong, X., Jiaxin, D., Jianzhong, Z. (2020). "The Psychological Impact of the COVID-19 Epidemic on College Students in China." Psychiatry Research, 287(March), 112934.

Coker, A. O., Coker, O., Sanni, D. (2018). "Psychometric Properties of the 21-Item Depression Anxiety Stress Scale (DASS-21)." African Research Review, 12(2), 135.

Darwish, S., Ahmed, U., \& Pahi, M. H. (2020). Innovative Work Behavior During COVID-19 for Medical Representative in the Pharmaceutical Industry: Test of a Moderation Model in Bahrain. International Journal of Pharmaceutical Research. 12(4), 1927-

1934. doi.org/10.31838/ijpr/2020.12.04.277

Dulmus, C. N., Carolyn, H. (2003). "When Stress Constitutes Trauma and Trauma Constitutes Crisis: The Stress-Trauma-Crisis Continuum." Brief Treatment and Crisis Intervention, 3(1), 27-36.

Gallo, E., Alejandra, G., Tiago, N. M., Christian, L. De. M., Joseph, M. (2018). "Gender Differences in the Effects of Childhood Maltreatment on Adult Depression and Anxiety: A Systematic Review and Meta-Analysis." Child Abuse and Neglect, 79(January), 107-14.

Gao, Q., Yingfu, H., Zhiguo, D., Feng, X., Jing, W., Jing, W. (2020). "The Epidemiological Characteristics of 2019 Novel Coronavirus Diseases (COVID-19) in Jingmen, China." SSRN Electronic Journal, 2(8),113-22.

Green, D. L., Naelys, D. (2008). “Gender Differences in Coping with Victimization.” Brief Treatment and Crisis Intervention, 8(2), 195-203.

Huang, Y., Ning, Z. (2020). "Mental Health Burden for the Public Affected by the COVID-19 Outbreak in China: Who Will Be the High-Risk Group?" Psychology, Health \& Medicine, 00(00),1-12.

Khan, S., Rabeea, S., Muhammad, A. S. (2020). "Impact of Coronavirus Outbreak on Psychological Health." (April).

Kuschner. (2017). "Issues of Health. HHS Public Access." Physiology \& Behavior, 176(3), 139-48.

Lee, S. A., Sherman, A. L. (2020). "Coronavirus Anxiety Scale : A Brief Mental Health Screener for COVID-19 Related Anxiety Coronavirus Anxiety Scale : A Brief Mental Health Screener for COVID-19 Related Anxiety." Death Studies, 0(0), 1-9.

Mark, G., Andrew, S. (2018). "Coping and Its Relation to Gender, Anxiety, Depression, Fatigue, Cognitive Difficulties and Somatic Symptoms." Journal of Education, Society and Behavioural Science, 25(4), 1-22.

Moutinho, I., Lúcia, D., Natalia, D. C., Pecci, M., Ronald, K. R., Alessandra, L., Granero, L., Sandra, H. 
INTERNATIONAL JOURNAL OF ACADEMIC RESEARCH IN BUSINESS AND SOCIAL SCIENCES

Vol. 10, No. 7, July, 2020, E-ISSN: 2222-6990 @ 2020 HRMARS

C., Tibiriç, Á., Oscarina, Da. S. E., Giancarlo, L. (2017). “Depression, Stress and Anxiety in Medical Students: A Cross-Sectional Comparison between Students from Different Semesters." Revista Da Associacao Medica Brasileira, 63(1), 21-28.

Piko, B. (2001). "Gender Differences and Similarities in Adolescents' Ways of Coping." Psychological Record, 51(2), 223-35.

Singh, V. (2020). "Effects of Stress in Psychological Health and Its Management." (April).

Sweileh, W. M. (2017). "Global Research Trends of World Health Organization's Top Eight Emerging Pathogens." Globalization and Health, 13(1), 1-19.

Tamres, L. K., Denise, J., Vicki, S. H. (2002). "Sex Differences in Coping Behavior: A Meta-Analytic Review and an Examination of Relative Coping." Personality and Social Psychology Review 6(1):2-30.

Wang, C., Riyu, P., Xiaoyang, W., Yilin, T., Linkang, X., Roger, S. M., Faith, N. C., Bach, T., Roger, H., Vijay, K. S., Cyrus, H. (2020). "A Longitudinal Study on the Mental Health of General Population during the COVID-19 Epidemic in China." Brain, Behavior, and Immunity, (April), 0-1.

Wang, Y., Yu, D., Junjie, Y., Wenbin, W. (2020). "Study on the Public Psychological States and Its Related Factors during the Outbreak of Coronavirus Disease 2019 (COVID-19) in Some Regions of China." Psychology, Health and Medicine 8506.

World Health Organization. (2020). "Proceedings of COVID 19 Public Health Emergency of International Concern Forum."

Wildman, W. J., Joseph, B., Richard, S., Uffe, S., Wesley, J. W., Joseph, B., Richard, S., Uffe, S. (2020). "Religion and the COVID-19 Pandemic." 5981.

Yusoff, N., Low, Y. W., Yip, C. H. (2010). "Reliability and Validity of the Brief COPE Scale (English Version) among Women with Breast Cancer Undergoing Treatment of Adjuvant Chemotherapy: A Malaysian Study." Medical Journal of Malaysia, 65(1), 41-44. 